DOI: $10.15193 /$ zntj/2017/112/204

\author{
MILENA LIPIŃSKA, MARZENA TOMASZEWSKA, \\ DANUTA KOŁOŻYN-KRAJEWSKA
}

\title{
ANALIZA SKALI MARNOTRAWSTWA ŻYWNOŚCI I MOŻLIWOŚCI JEJ OGRANICZANIA NA ETAPIE TRANSPORTU PRODUKTÓW MLECZARSKICH Z WYKORZYSTANIEM METODY „MUDA”
}

Streszczenie

Strata, zwana także marnotrawstwem (w jęz. japońskim „muda”), definiowana jest jako aktywność pochłaniająca zasoby bez tworzenia wartości dla klienta. Straty zajmują wiele czasu w procesie produkcyjnym. W związku z tym należy szukać rozwiązań eliminujących marnotrawstwo, które nie przynosi zysków oraz skupić się na czynnościach dodających wartość.

Celem pracy była próba zastosowania klasyfikacji „muda” do analizy strat i marnotrawstwa produktów mleczarskich na etapie ich dystrybucji i transportu. Klasyfikacja "muda" wyróżnia osiem podstawowych kategorii (nadprodukcja, zapasy, braki, ruch, przetwarzanie, oczekiwanie, transport oraz niewykorzystanie potencjału ludzkiego), w kontekście których rozpatrzono problem marnotrawstwa procesów oraz zasobów. Opracowania dokonano na podstawie przeglądu dostępnej literatury z zakresu marnotrawstwa żywności na etapie transportu wyrobów mleczarskich.

Na podstawie analizy wykazano, że na etapie transportu produktów mleczarskich występują problemy ujęte we wszystkich kategoriach klasyfikacji „muda”. Mimo stosowania obowiązujących zasad podczas transportu produktów mleczarskich w pewnych obszarach nadal brakuje działań, które przyczynią się do zmniejszenia skali strat i marnotrawstwa żywności na tym etapie. Największa masa strat powstająca podczas transportu wyrobów mleczarskich związana jest z koniecznością zachowania łańcucha chłodniczego w czasie całego transportu, szczególnie produktów z krótkim terminem przydatności do spożycia. Przyczyną niedostarczania produktów do odbiorcy w odpowiednim czasie z zachowaniem ciągłości łańcucha chłodniczego są uszkodzenia urządzeń chłodniczych oraz jednostek transportowych. Istotny czynnik przy powstawaniu strat stanowią także błędy popełniane przez ludzi od momentu załadunku do momentu wyładunku produktów u odbiorcy, które przyczyniają się do powstawania uszkodzeń mechanicznych opakowań. Odnalezienie i wyeliminowanie wszystkich strat klasyfikowanych według kategorii "muda" pozwoli na usprawnienie procesów oraz zmniejszenie ponoszonych niepotrzebnie kosztów na poszczególnych etapach transportu produktów mleczarskich.

Mgr inż. M. Lipińska, dr inż. M. Tomaszewska, prof. dr hab. D. Kołożyn-Krajewska, Katedra Technologii Gastronomicznej i Higieny Żywności, Wydz. Nauk o Żywieniu Człowieka i Konsumpcji, Szkoła Główna Gospodarstwa Wiejskiego, ul. Nowoursynowska 159 C, 02-776 Warszawa.

Kontakt:milena_lipinska@o2.pl 
Słowa kluczowe: produkty mleczne, marnotrawstwo, transport, klasyfikacja „muda”

\section{Wprowadzenie}

Problem strat i marnotrawstwa jest jednym z elementów ograniczających możliwość wykorzystania żywności do zaspokojenia podstawowych potrzeb człowieka [1]. FAO definiuje marnotrawstwo żywności jako, „żywność konsumpcyjną, z wyłączeniem części niejadalnych, która nie została spożyta przez człowieka oraz żywność przeznaczoną na cele nieżywnościowe" [4]. Beretta i wsp. [2] dokonali podziału marnotrawstwa żywności na trzy kategorie:

- do uniknięcia: pojęcie to odnosi się do produktów, których znacznie niższa jakość jest konsekwencją niewykorzystania ich w odpowiednim czasie lub przechowywania w niewłaściwych warunkach;

- możliwe do uniknięcia: dotyczy tych produktów, które w zależności od preferencji są zjadane tylko przez pewną grupę konsumentów, np. skórki jabłek, produkty z wadami wyglądu, w tym niekształtne warzywa (marchew) oraz te produkty, które konsumenci spożywają w zależności od sposobu ich przygotowania: skórki ziemniaka są zjadane wówczas, gdy jest on gotowany i podawany ze skórką;

- niemożliwe do uniknięcia: odnosi się do niejadalnych elementów np. gniazda nasienne, skórki niektórych owoców (banan), liście herbaty itp.

Problem marnotrawstwa żywności wiąże się z niepożądanymi skutkami. Z uwagi na skalę głodu i niedożywienia na świecie wyrzucanie żywności jest działaniem nieetycznym. Ponadto marnotrawstwo żywności ogranicza bezpieczeństwo żywnościowe w skali kraju, powoduje bezpowrotną utratę środków pieniężnych przeznaczonych na produkcję żywności, stanowi istotne zagrożenie dla środowiska naturalnego, powoduje nieracjonalne zużycie wody i innych zasobów naturalnych oraz marnotrawstwo energii skumulowanej w wyrzucanych produktach [6].

Golińska-Dawson i wsp. [5] przedstawiają bardziej szczegółową definicję marnotrawstwa według klasyfikacji „muda”, które odnosi się nie tylko do utraty masy żywności przeznaczonej do konsumpcji, ale także do procesów i zasobów wykorzystywanych do produkcji żywności. Strata, zwana także marnotrawstwem (w języku japońskim „muda”), definiowana jest jako aktywność, która pochłania zasoby, bez tworzenia wartości dla klienta wewnętrznego i zewnętrznego. Powstawanie strat powoduje utratę czasu w procesie produkcyjnym, w związku z czym należy szukać rozwiązań eliminujących marnotrawstwo, które nie przynosi zysków oraz skupić się na czynnościach dodających wartość. Wspomniana klasyfikacja „muda” wyróżnia osiem kategorii: nadprodukcję, zapasy, braki, ruch, przetwarzanie, oczekiwanie, transport oraz niewykorzystanie potencjału ludzkiego [12]. W koncepcji zrównoważonego roz- 
woju wymienione kategorie analizuje się w trzech aspektach: społeczeństwa, ekonomii i środowiska [5].

Nadprodukcja jest to produkowanie szybciej i więcej niż jest to konieczne. Jest ona najniebezpieczniejszym marnotrawstwem i powstaje, gdy producent nie analizuje potrzeb rynkowych, co prowadzi do tego, że na półki sklepowe trafiają produkty, na które nie ma aktualnie zapotrzebowania. Nadmierne zapasy zajmują powierzchnie magazynowe, często wymagają tworzenia lub dzierżawy nowych powierzchni do składowania, sprzętu do operowania zapasami oraz obciążają pracowników. Braki i wadliwe wyroby są to produkty, które nie spełniają wymagań klientów, natomiast straty przy przetwarzaniu spowodowane mogą być zastosowaniem nieadekwatnych maszyn, nadmiernego ich przeciążenia oraz uszkodzenia. Nadmierna liczba kursów oraz nadmierne obciążenie środka transportu prowadzą do licznych wypadków, w wyniku których uszkodzeniu ulegają przewożone produkty. Straty powstające na skutek błędów ludzkich klasyfikowane są w postaci dwóch problemów: zbędnego ruchu pracowników oraz niewykorzystania potencjału pracowników. Problemy te można w pewnym stopniu wyeliminować poprzez prowadzenie szkoleń oraz obserwację pracy przez przełożonych. Ostatnim elementem klasyfikacji ,muda” jest oczekiwanie, które odnosi się do sytuacji, gdy pracownik nie wykonuje żadnych czynności z zakresu powierzonych mu obowiązków.

Celem pracy była próba zastosowania metody „muda” do analizy strat i marnotrawstwa produktów mleczarskich na etapie ich dystrybucji i transportu. Opracowania dokonano na podstawie przeglądu dostępnej literatury z zakresu marnotrawstwa żywności na etapie transportu wyrobów mleczarskich.

\section{Identyfikacja marnotrawstwa w klasyfikacji „muda” na przykladzie transportu wyrobów mleczarskich}

Pierwszą kategorią marnotrawstwa wyodrębnioną przez twórców koncepcji „muda" jest nadprodukcja. Biorąc pod uwagę aspekty ekonomiczne: nadprodukcja wiąże się z nadmiernym kupowaniem surowców, które stanowią zamrożony kapitał firmy oraz powstawaniem innych kategorii „muda”, np. nadmierne zapasy, których utrzymywanie generuje dodatkowe koszty. W przypadku produkcji wyrobów mleczarskich są to głównie surowce, które wymagają chłodniczego magazynowania. Ponadto nadprodukcja prowadzi do przeciążenia maszyn, które w konsekwencji wymagają częstszych napraw lub wymiany, pracownicy są przemęczeni i oczekują zwiększenia wynagrodzeń. Nadmierna produkcja to również niekorzystny wpływ na środowisko poprzez zwiększoną ilość odpadów, wzrost zanieczyszczenia środowiska oraz zwiększone zużycie energii i zasobów naturalnych [5].

Nadprodukcja jest bezpośrednio związana z kolejną kategorią „muda”, tj. z nadmiernymi zapasami, które mogą występować na każdym etapie produkcji. W czasie 
długotrwałego magazynowania produktów mleczarskich może dochodzić do zepsucia, kradzieży lub obniżenia jakości produktów. Ponadto wzrastają koszty związane z utylizacją (np. produktów przeterminowanych) oraz dochodzi do tzw. zamrożenia kapitału w zapasach [5]. Precyzyjnie prowadzone procesy planowania i realizacji zamówień pozwalają na wyeliminowanie problemu nadprodukcji, unikanie konieczności długotrwałego i kosztownego magazynowania oraz zbędnej pracy sprzętu czy też ludzi. Utrzymywanie dużych zapasów produktów, zwłaszcza produktów mleczarskich, jest działaniem niekorzystnym, gdyż duża część tego asortymentu ma krótki termin przydatności do spożycia, zatem czas na dostarczenie ich do odbiorcy jest ograniczony. Działaniem mającym na celu minimalizowanie powstawania nadmiernych zapasów jest produkowanie ilości produktów mleczarskich, na które istnieje realne zapotrzebowanie. Pozwala to na racjonalne gospodarowanie wyrobami i unikanie problemu zbliżających się terminów przydatności do spożycia. Lipińska i wsp. [9] wykazali, że krótkie terminy przydatności do spożycia produktów mleczarskich stanowiły istotny czynnik wykluczający towar z dalszego obrotu na etapie transportu. Wykazano, że na przestrzeni dwóch lat zwroty $\mathrm{z}$ tytułu zbyt krótkiego terminu przydatności do spożycia stanowiły $0,4 \%$ wszystkich zwrotów. Było to związane z niewłaściwym zarządzaniem produktem, w wyniku którego powstawał problem zbyt krótkiego czasu na dostarczenie towaru na półki sklepowe. Odbiorcy odmawiają przyjmowania takich produktów, gdyż klienci w pierwszej kolejności zwracają uwagę na termin przydatności do spożycia, następnie datę produkcji oraz skład produktu [7]. Ze względu na krótki termin przydatności do spożycia produkty mleczarskie charakteryzuje duża rotacja, w związku z czym nie występuje problem nadmiernego gromadzenia zapasów. Często praktykowanym działaniem w różnych zakładach jest sprzedaż produktów o kończącym się terminie przydatności do spożycia pracownikom lub w sklepach firmowych.

Braki i wadliwe wyroby powodują utratę reputacji oraz pochłaniają środki na ich zakup. Wymagają ponownego przetworzenia, utylizacji lub obsługi reklamacji, czasem mogą prowadzić do obciążeń karami finansowymi bądź utraty kontrahentów. Ze względu na aspekt środowiskowy do otoczenia trafia nadmierna ilość trudnych do przetworzenia odpadów [5]. Badania przeprowadzone w wybranych dwóch spółdzielniach mleczarskich z Wielkopolski wskazały, że najczęstszą przyczyną braków na etapie transportu były uszkodzenia mechaniczne. W wyniku tego typu uszkodzeń w ciągu jednego roku w badanych jednostkach odmówiono przyjęcia 1930 kg produktów mleczarskich. Jako główne rodzaje uszkodzeń zdefiniowano zewnętrzną deformację opakowania oraz uszkodzenia powodujące przerwanie bariery ochronnej opakowania [11]. Analiza rodzaju tworzyw wykorzystywanych do pakowania produktów mleczarskich umożliwia stwierdzenie, że charakteryzuje je wysoka podatność na uszkodzenia w czasie transportu. Przykładem mogą być opakowania kartonowe, które łatwo ulegają zgnieceniom, zwłaszcza w dolnych warstwach palety, oraz w czasie ko- 
lizji na skutek przesunięcia lub przewrócenia palety. Alternatywą dla tego rodzaju opakowań mogą być butelki, gdyż jak podkreśla Robertson [10], w przypadku butelki PET ten rodzaj uszkodzeń występuje rzadziej niż w przypadku opakowania kartonowego. W celu znacznego ograniczenia opisanego zjawiska należy równo układać produkty na palecie, zabezpieczyć je folią oraz uważnie prowadzić procesy załadunku i wyładunku [3].

Wrzosek i wsp., [13] zwracają także uwagę na opakowania takich produktów, jak: serki, kefiry i maślanki, czyli pakowane w kubki z aluminiowym wieczkiem, którego delikatność ma duże znaczenie przy licznych uszkodzeniach. Wszystkie błędy i wady jakościowe produktów na etapie transportu warunkowane są nieodpowiednią organizacją pracy, nieodpowiednim przeszkoleniem personelu czy też nieuwagą lub brakiem kwalifikacji kierowców i osób obsługujących wózki widłowe podczas załadunku i rozładunku.

Straty przy przetwarzaniu, w przypadku transportu mleczarskich wyrobów gotowych, powstają na skutek awarii jednostek transportowych lub urządzeń chłodniczych. Prowadzić to może do frustracji pracowników, wypadków oraz wzrostu kosztów napraw [5]. W czasie transportu istnieje możliwość występowania zepsutych/uszkodzonych produktów, jednak powstają one wyłącznie na skutek błędów pracowników lub zdarzeń losowych (wypadków, kolizji, uszkodzeń urządzeń). W przypadku przewozu produktów mleczarskich niezmiernie ważne jest zachowanie odpowiedniej temperatury w czasie załadunku, transportowania oraz rozładunku towarów. Niedotrzymanie warunków chłodniczych generuje straty, dlatego należy skupić na tym elemencie szczególną uwagę. Powszechnie wykorzystywanym narzędziem do pomiaru temperatury są rejestratory elektroniczne, które dokonują pomiarów co 15 30 min oraz mogą monitorować czas otwarcia drzwi. Udogodnieniem przy zastosowaniu tego typu rejestratorów jest możliwość wygenerowania wydruków temperaturowych z całego czasu trwania transportu. Bardzo ważna w tym zakresie jest także kontrola temperatury po dostarczeniu towaru do odbiorcy, która obejmuje sprawdzenie temperatury produktów oraz panującej wewnątrz przestrzeni ładunkowej pojazdu. Zdarzają się także sytuacje losowe, które mogą spowodować uszkodzenie urządzeń chłodniczych. W sytuacji wypadku czy kolizji, na skutek czego dochodzi do uszkodzeń agregatu lub problemów z utrzymaniem temperatury chłodniczej, stosowana jest praktyka przeładunku transportowanego towaru w celu uniknięcia strat [8].

Transport jest niezbędnym elementem w zapewnianiu klientom dostępności oferowanych produktów, jednak zbędne przenoszenie materiałów, części i produktów pomiędzy procesami nie powoduje wzrostu wartości dodanej. Zbędny oraz złożony przepływ rzeczy powoduje stratę czasu i powierzchni produkcyjnej. Źle zaplanowany transport zewnętrzny zwiększa ryzyko wystąpienia wypadków przy pracy oraz wpływa na zwiększenie uszkodzeń produktu przy przeładunkach i samym przemieszczaniu 
towaru. W związku z powyższym wzrastają koszty związane z transportem, tj. koszty paliwa i napraw oraz zwiększa się negatywny wpływ na środowisko (spaliny, energia, akumulatory - odpady niebezpieczne) [5]. Odpowiednio zorganizowana strefa załadunku i rozładunku w zakładach przetwórstwa mlecznego pozwala osobom odpowiedzialnym za te czynności przeprowadzać prace szybko i sprawnie. Zachowanie funkcjonalności w tych strefach usprawnia samą pracę manipulacyjną wózkiem widłowym oraz wpływa korzystnie na produkt, ponieważ nie dochodzi do zmian temperatury produktu na skutek długo prowadzonych załadunków i wyładunków.

W badaniach własnych Lipińska i wsp. [9] stwierdziły, że w 2014 r., w analizowanej spółdzielni mleczarskiej miały miejsce trzy kolizje, co stanowiło 0,03 \% kursów realizowanych rocznie. W ich wyniku zostało uszkodzonych 60120 sztuk opakowań mleka UHT. Zdarzenia te spowodowały konieczność poniesienia dodatkowego kosztu utylizacji uszkodzonych produktów i napraw środków transportu. Ponadto powstał problem zastąpienia uszkodzonych jednostek transportowych innymi samochodami, gdyż terminowe dostarczanie produktów jest priorytetem dla badanej jednostki.

W klasyfikacji „muda” przedstawia się problemy pracownicze w postaci dwóch kategorii. Jedną z nich jest zbędny ruch pracowników, który nie ma wartości dodanej, nadmierne ich obciąża, co zwiększa ryzyko wypadków, chorób czy konfliktów między pracownikami. Może to doprowadzić do konieczności zwiększenia zatrudnienia, a w konsekwencji wzrostu kosztów. Drugą kategorią jest niewykorzystanie potencjału pracowników. Problem ten może doprowadzić wśród pracowników do takich stanów, jak: brak motywacji, przemęczenie, znużenie, a nawet obniżenie opinii o pracodawcy [5].

Lipińska i wsp. [9] wykazali, że istotnym problemem z tej kategorii są liczne obowiązki kierowców związane z transportem mleczarskich wyrobów gotowych, które powodują pośpiech pracowników, co może prowadzić do powstawania strat produktów w czasie ich transportu. Wszyscy kierowcy odpowiedzialni byli za przemieszczanie ładunku środkiem transportu. W wielu jednostkach transportowych odpowiedzialność kierowców była poszerzona o zadania: załadunek do środka transportu (76\% wskazań), wyładunek towaru u odbiorcy (70 \% wskazań), pobieranie towaru z miejsca składowania (63\% wskazań), przygotowanie jednostek ładunkowych (48\% wskazań), dostarczenie do strefy kompletacji ( $28 \%$ wskazań) oraz przemieszczanie do miejsca składowania u odbiorcy ( $26 \%$ wskazań).

Ostatnim elementem w klasyfikacji „muda” jest oczekiwanie, czyli moment między zakończeniem jednego procesu a rozpoczęciem kolejnego. Oczekiwanie powoduje straty związane z niewykorzystaniem potencjału pracowników i maszyn, marnotrawieniem czasu oraz niedotrzymywaniem terminów [5]. Problemy pracownicze i straty związane z uszkodzeniem maszyn (w przypadku transportu wyrobów gotowych dotyczy to samochodów oraz agregatów) zostały omówione powyżej. Istotny problem 
Tabela 1. Problem marnotrawstwa w kategorii „muda” na przykładzie transportu produktów mleczarskich Table 1. Issue of waste in "muda" category exemplified by transport of dairy products

\begin{tabular}{|c|c|c|}
\hline \multirow{2}{*}{$\begin{array}{c}\text { Kategoria w klasyfikacji } \\
\text { „muda” } \\
\text { Category in } \\
\text { classification „muda” }\end{array}$} & \multicolumn{2}{|c|}{$\begin{array}{l}\text { Sytuacja w spółdzielni mleczarskiej na przykładzie transportu } \\
\text { produktów mleczarskich }\end{array}$} \\
\hline & $\begin{array}{l}\text { Zdefiniowane problemy / Problems } \\
\text { defined }\end{array}$ & $\begin{array}{c}\text { Stosowane rozwiązania } \\
\text { Solutions used }\end{array}$ \\
\hline $\begin{array}{c}\text { Nadprodukcja } \\
\text { i nadmierne zapasy } \\
\text { Overproduction and } \\
\text { excessive stocks }\end{array}$ & $\begin{array}{c}\text { Odmowa przyjęcia przez odbiorcę } \\
\text { towarów o bliskim terminie przydatno- } \\
\text { ści do spożycia } \\
\text { Recipient refuses to accept goods with } \\
\text { close expiry date }\end{array}$ & $\begin{array}{c}\text { Dokładne prowadzenie procesów } \\
\text { przyjmowania zamówień. } \\
\text { Dowóz ilości, na które istnieje } \\
\text { realne zapotrzebowanie. } \\
\text { Terminowe dostarczanie } \\
\text { zamawianych ilości. } \\
\text { Sprzedaż pracownikom oraz w } \\
\text { sklepach firmowych. } \\
\text { Precisely handling order acceptance } \\
\text { processes. } \\
\text { Delivery of quantities that are really } \\
\text { demanded. } \\
\text { Timely delivery of ordered } \\
\text { quantities. } \\
\text { Sales to employees and in company } \\
\text { stores. }\end{array}$ \\
\hline $\begin{array}{c}\text { Braki, wadliwe wyroby } \\
\text { Shortages, defective } \\
\text { products }\end{array}$ & $\begin{array}{l}\text { Uszkodzenia mechaniczne produktów } \\
\text { Mechanical damage to products }\end{array}$ & Brak / None \\
\hline $\begin{array}{c}\text { Straty przy } \\
\text { przetwarzaniu, transport } \\
\text { Losses during pro- } \\
\text { cessing, transport }\end{array}$ & $\begin{array}{c}\text { Wypadki, kolizje, uszkodzenia maszyn } \\
\text { i opakowań produktów. } \\
\text { Problemy z utrzymaniem chłodniczej } \\
\text { temperatury w czasie transportu } \\
\text { Accidents, collisions, damage to ma- } \\
\text { chinery and packaging products. } \\
\text { Problems with maintaining cooling } \\
\text { temperature during transport }\end{array}$ & $\begin{array}{c}\text { Sprawnie prowadzone procesy } \\
\text { załadunku i wyładunku towarów. } \\
\text { Przeładunek nieuszkodzonego } \\
\text { towaru na inny samochód i dalszy } \\
\text { jego przewóz. } \\
\text { Efficiently conducted processes of } \\
\text { loading and unloading goods. } \\
\text { Trans-shipment of undamaged } \\
\text { goods to another car and its further } \\
\text { transport }\end{array}$ \\
\hline $\begin{array}{c}\text { Zbędny ruch } \\
\text { pracowników, } \\
\text { niewykorzystanie } \\
\text { potencjału pracowników } \\
\text { Unnecessary movement } \\
\text { of staff, untapped } \\
\text { potential of employees }\end{array}$ & $\begin{array}{l}\text { Liczne obowiązki pracowników (często } \\
\text { zbyt liczne, co powoduje kolejny } \\
\text { problem: pośpiech pracowników } \\
\text { przyczynia się do powstawania strat) } \\
\text { Numerous employee duties (often too } \\
\text { numerous, and this causes another } \\
\text { problem: staff works under time pres- } \\
\text { sure and this contributes to losses) }\end{array}$ & Brak / None \\
\hline $\begin{array}{l}\text { Oczekiwanie } \\
\text { Waiting }\end{array}$ & $\begin{array}{c}\text { Niezachowanie odpowiedniej } \\
\text { temperatury w przestrzeni ładunkowej } \\
\text { na skutek częstego otwierania drzwi } \\
\text { Proper temperature is not maintained in } \\
\text { cargo space because door is frequently } \\
\text { opened }\end{array}$ & Brak / None \\
\hline
\end{tabular}


w spółdzielniach mleczarskich stanowią zmiany temperatury w przestrzeni załadunkowej jednostek transportujących wyroby gotowe. Jak wskazuje Żarnecka [14], obowiązkiem pracownika jest zapewnienie ciągłości odpowiedniej temperatury w czasie transportu. Dopuszcza się jedynie krótkotrwałe przerwanie łańcucha chłodniczego wyłącznie w czasie przygotowywania towaru, jego załadunku bądź wyładunku oraz wystawiania na sprzedaż. Szczególne znaczenie ma transport artykułów mleczarskich nietrwałych w porze letniej. Nieprzestrzeganie odpowiednich procedur może doprowadzić do wzrostu temperatury wewnątrz przestrzeni ładunkowej środka transportu, co powoduje wzrost temperatury samego produktu [8].

$\mathrm{Na}$ podstawie przeprowadzonej analizy marnotrawstwa produktów mleczarskich według klasyfikacji „muda” można stwierdzić, że w badanej jednostce transportowej istnieje kilka obszarów, w których występuje omawiany problem, co przedstawiono w tab. 1.

\section{Podsumowanie}

Z przeprowadzonej analizy wynika, że najczęściej występującymi problemami są uszkodzenia opakowań oraz krótkie terminy przydatności produktów do spożycia. Powoduje to wyeliminowanie partii towarów z dalszego obrotu oraz generuje dodatkowe koszty. Kolejnym istotnym elementem przyczyniającym się do marnotrawstwa na etapie transportu wyrobów gotowych są uszkodzenia urządzeń chłodniczych. Długotrwałe przewożenie towarów w nieodpowiedniej temperaturze powoduje zepsucie produktów, które ostatecznie muszą być zutylizowane. Na omawianym etapie zidentyfikowano problemy marnotrawstwa definiowane według klasyfikacji „muda”, lecz brakuje skutecznie prowadzonych działań mających na celu ich eliminację. W związku $\mathrm{z}$ tym, w badanej jednostce istnieje potrzeba udoskonalenia niektórych procesów oraz przeprowadzenia np. dodatkowych szkoleń pracowniczych, gdyż czynnik ludzki ma istotne znaczenie $\mathrm{w}$ powstawaniu strat.

\section{Literatura}

[1] Barłowska J., Florek M., Litwińczuk Z.: Produkcja żywności ilość czy jakość? Cz. I. Przem. Spoż., 2016, 2 (70), 8-12.

[2] Beretta C., Stoessel F., Baier U., Hellweg S.: Quantifying food losses and the potential for reduction in Switzerland. Waste Management, 2013, 33, 764-773.

[3] Bomba I.: Algorytm projektowania jednostki paletowej. Logistyka, 2011, 3, 207-213.

[4] FAO: Global food losses and food waste. 2011. [on-line]. Dostęp w Internecie [28.09.2016]: www.fao.org

[5] Golińska-Dawsnon P., Kosacka M., Werner-Lewandowska K.: Gdzie i jak usprawniać procesy? Identyfikacja potencjałów optymalizacyjnych przez analizę marnotrawstw (muda) w perspektywie zrównoważonego wykorzystania zasobów. Logistyka, 2015, 2, 167-178.

[6] Krajewski K., Lipińska M., Wrzosek M., Bilska B., Kołożyn-Krajewska D.: Food waste - four dimensions of security: Economic, social, energy and environmental. Intercathedra, 2016, 32 (2), 47-53. 
[7] Krasnowska G., Salejda A.: Ocena wiedzy konsumentów na temat znakowania żywności. Żywność. Nauka. Technologia. Jakość, 2011, 1 (74), 173-189.

[8] Lipińska M., Tomaszewska M.: Skala i przyczyny strat mleka i produktów mleczarskich w transporcie. W: Model ograniczania strat i marnowania żywności z korzyścią dla społeczeństwa (MOST). Red. B. Bilska i D. Kołożyn-Krajewska. Wyd. Nauk. PTTŻ, Kraków 2016, ss. 38-46.

[9] Lipińska M., Tomaszewska M., Kołożyn-Krajewska D.: Problem strat w łańcuchu żywnościowym na przykładzie transportu wyrobów mleczarskich. Zesz. Probl. Post. Nauk Roln., 2016, 584, 61-70.

[10] Robertson G.L.: Food Packaging: Principles and practice. $3^{\text {rd }}$ ed. CRC Press, Boca Raton 2013.

[11] Tomaszewska M., Lipińska M., Kołożyn-Krajewska D., Grodzicki A.: Analiza strat na etapie transportu mleka i jego przetworów w wybranych spółdzielniach mleczarskich z Wielkopolski. Stowarzyszenie Ekonomistów Rolnictwa i Agrobiznesu, Rocz. Nauk., 2016, XVIII (3), 352-357.

[12] Wahab A.N.A., Mukhtar M., Sulaiman R.: A conceptual model of lean manufacturing dimensions. Procedia Technology, 2013, 11, 1292-1298.

[13] Wrzosek M., Bilska B., Kołożyn-Krajewska D., Krajewski K.: Określenie skali i przyczyn strat żywności w handlu detalicznym na przykładzie mleka i jego przetworów. Żywność Nauka. Technologia. Jakość, 2014, 2 (93), 225-238.

[14] Żarnecka M.: Przechowywanie mleka i produktów mleczarskich. Przegl. Mlecz., 2015, 7, 3-5.

\title{
ANALYSIS OF MAGNITUDE OF FOOD WASTE AND POSSIBILITY TO REDUCE IT USING "MUDA" METHOD AT THE STAGE OF TRANSPORTING DAIRY PRODUCTS
}

\author{
$\mathrm{S} u \mathrm{~mm}$ a r y
}

Loss, also called waste (in Japanese "muda"), is defined as the activity that consumes resources without creating any value for customers. Losses take up a lot of time during the production process. Therefore, solutions should be sought to eliminate wastage that does not bring profits, and to focus on the value added activities.

The objective of the study was an attempt to apply the "muda" classification to analyse the losses and waste in dairy products at the stage of their distribution and transportation. The "muda" classification comprises eight basic categories (overproduction, stocks, shortages, traffic, processing, waiting, transport, and unused human potential). The issue of waste in processes and resources was approached and studied in the context of those categories. The study was performed on the basis of a review of reference literature available dealing with food waste at the stage of transporting dairy products.

Based on the analysis, it was shown that during the transportation of dairy products, the problems that occurred were included in all the categories of the "muda" classification. Although the rules obligatory for the transportation of dairy products have been applied, there are still some shortcomings in specific areas that could contribute to reducing the magnitude of food waste and losses at this stage. During the transportation of dairy products, the highest loss that occurs is attributed to the indispensability of maintaining the refrigerated chain throughout the entire transport, in particular in the case of the products with a short shelf life. Breakages in the cooling equipment and transportation units are the reason why products are not delivered to the customer in due time with the continuity of the refrigeration chain ensured. Another significant losses-generating factor are mistakes made by people from the moment of loading to the moment of unloading the products at the customer's; they contribute to mechanical damage of the packaging. Finding and eliminating all the losses classified according to the "muda" category will make it possible to streamline the processes and to reduce unnecessary costs incurred at individual stages of transporting dairy products.

Key words: dairy products, wastage, transport, "muda' classification 